\title{
Does the transcription factor AP-2 $\beta$ have an impact on the genetic and early environmental influence on ethanol consumption?
}

\author{
S. Oreland $\cdot$ L. Daoura $\cdot$ L. Gustafsson-Ericson • \\ M. Damberg $\cdot$ P. Hyytiä $\cdot$ L. Oreland $\cdot$ \\ Ingrid Nylander
}

Received: 26 February 2010/ Accepted: 9 July 2010/Published online: 6 August 2010

(C) The Author(s) 2010. This article is published with open access at Springerlink.com

\begin{abstract}
Genes involved in alcoholism have consensus sites for the transcription factor activator protein (TFAP) $2 \beta$. In the present study, we investigated TFAP- $2 \beta$ protein levels in the ethanol-preferring alko, alcohol (AA) and the ethanol-avoiding alko, non-alcohol (ANA) rat lines. Furthermore, basal and ethanol-induced TFAP- $2 \beta$ levels were examined in Wistar rats exposed to different early postnatal environments that are known to affect later ethanol consumption. Taken together, we found differences in brainstem TFAP- $2 \beta$ protein between the AA and ANA rats.
\end{abstract}

Keywords AA (alko, alcohol) rats · ANA (alko, nonalcohol) rats · Early-life experience · Free-choice drinking paradigm $\cdot$ Handling $\cdot$ Maternal separation

\section{Introduction}

The implication of gene-environment interactions in the etiology of psychiatric diseases, such as depression and

S. Oreland · L. Daoura · L. Gustafsson-Ericson .

I. Nylander $(\square)$

Division of Pharmacology, Department of Pharmaceutical

Biosciences, Uppsala University, P.O. Box 591,

75124 Uppsala, Sweden

e-mail: Ingrid.Nylander@farmbio.uu.se

M. Damberg · L. Oreland

Division of Pharmacology, Department of Neuroscience,

Uppsala University, Uppsala, Sweden

P. Hyytiä

Department of Mental Health and Alcohol Research,

National Public Health Institute, P.O. Box 33,

00251 Helsinki, Finland drug addiction is well established in humans (Caspi et al. 2002; Nilsson et al. 2007) and non-human primates (Barr et al. 2003). In rodents, the maternal separation (MS) model is widely used to assess long-term consequences of different early experiences (Ladd et al. 2000; Pryce and Feldon 2003). MS has been shown to strongly affect the neurocircuitries involved in drug addiction and also cause long-term effects on the propensity to voluntarily drink ethanol (Gustafsson et al. 2008; Oreland et al. 2009; Ploj and Nylander 2003; Ploj et al. 2002, 2003b). In the compulsive use of ethanol, neurotransmitter systems such as dopamine, serotonin, noradrenaline and opioids are involved (Koob and Volkow 2010). One common factor affecting the development of these neural systems is the transcription factor activator protein (TFAP) $2 \beta$ (Comb et al. 1988; Damberg 2005). The TFAP-2 $\beta$ may, therefore, be a target for early environmental influences and a mediator of the effects seen after MS. Interestingly, early environmental factors have been associated with altered TFAP-2 family gene expression in rats (Meaney et al. 2000). In the present study, the aim was to examine possible differences in brainstem TFAP- $2 \beta$ levels in animals genetically or environmentally predisposed to prefer high ethanol drinking and high ethanol concentration. Besides rats subjected to MS, the ethanol-preferring alko, alcohol (AA) and the ethanol-avoiding alko, non-alcohol (ANA) rats were studied. The AA and ANA lines are among the first rodent lines produced by bidirectional selection for high ethanol preference in a two-bottle choice between ethanol and water (for review see Sommer et al. 2006). Three experiments were performed: I comparative analysis of TFAP- $2 \beta$ levels in the AA and ANA rats, II assessment of TFAP- $2 \beta$ levels in juvenile and adult rats subjected to different early environmental conditions using the MS model, and III analysis of the impact of long-term 
voluntary ethanol consumption on adult rats reared in different early environmental conditions.

\section{Materials and methods}

Experiment I Twelve alcohol-naïve adult male AA and ANA rats were obtained from the National Public Health Institute, Finland. Upon arrival, the rats were housed with 3 rats per cage in standard macrolon cages $(59 \times 38 \times 20 \mathrm{~cm})$ containing wood-chip bedding material. Experiment II and III Time-mated pregnant Wistar rats (Scanbur AB, Sweden) arrived at the animal facility on gestational day 14-15 (Experiment II) and 12-13 (Experiment III). The pregnant rats were singly housed in macrolon cages. On the day of birth, postnatal day (PND) 0, the litters were divided into litters of 9-10 pups (males, $n=5-6$; females, $n=3-4$ ). MS was performed during PNDs 1-21. The rat pups were subjected to daily $15 \mathrm{~min}$ (MS15) or $360 \mathrm{~min}$ (MS360) MS or conventional animal facility rearing (AFR). The MS procedures have previously been described in detail elsewhere (Gustafsson and Nylander 2006). In adulthood, animals in Experiment III were singly housed from PND 73-75 and were then given free access to 5, 10 and 20\% (v/v) ethanol solutions and one bottle with water (MS15E, MS360E and AFRE) or just water (MS15W and MS360W) for 54 days. The four-bottle choice paradigm is described in detail elsewhere (Gustafsson and Nylander 2006). The AA and ANA males were decapitated at 25 weeks of age. The rats exposed to MS in Experiment II were sacrificed at 3 and 10 weeks, respectively, and rats in Experiment III at the end of the ethanol-drinking period. The brainstems were removed and immediately frozen on dry ice and stored at $-80^{\circ} \mathrm{C}$ until further analysis. Nuclear proteins were extracted according to our previous protocol (Berggard et al. 2003). Total protein concentration was determined using the Lowry method (Lowry et al. 1951). All animals had free access to water and R36 Labfor food pellets (Lactamin AB, Sweden) in a humidity- and temperature-controlled environment. All animal experiments were performed in accordance with the European Communities Council Directives (86/609/EEC). An overview of experimental procedure is outlined in Fig. 1.

With some modifications, TFAP- $2 \beta$ levels were analyzed using enzyme-linked immunosorbent assay as earlier described (Berggard et al. 2003). The nuclear extracts were diluted 1:5 with carbonate-bicarbonate buffer $\mathrm{pH}$ 9.6. $50 \mu \mathrm{l}$ of $14 \mu \mathrm{g} / \mathrm{ml}$ goat polyclonal TFAP- $2 \beta$ primary antibody (SDS Biosciences, Sweden) together with $50 \mu \mathrm{l}$ of $1.5 \mu \mathrm{g} / \mathrm{ml}$ donkey anti-goat IgG AP conjugated secondary antibody (SDS Biosciences, Sweden) was added per well. $25 \mathrm{~min}$ after adding $50 \mu \mathrm{l}$ of phosphatase substrate solution, an additional $50 \mu \mathrm{l}$ of stop solution $(3 \mathrm{M} \mathrm{NaOH})$ was added. The optical density was measured at $405 \mathrm{~nm}$. The immunoreactive (ir) TFAP- $2 \beta$ in each sample was deciphered from a standard curve, where known $\log _{10}$ transformed concentrations of ir TFAP- $2 \beta$ peptide (SDS Biosciences, Sweden) were plotted against optical density using AssayZap v3.1 (Biosoft ${ }^{\circledR}, \mathrm{UK}$ ).

A one-way analysis of variance (ANOVA) followed by Fisher's protected least significant differences (PLSD) post-hoc test was performed to compare ir TFAP- $2 \beta$ levels between I AA and ANA male rats, II MS15l, MS360l, and AFR male rats at 3 and 10 weeks of age, respectively, and III MS15W, MS360W, MS15E, MS360E and AFRE male rats. Two-way ANOVA followed by Fisher's PLSD posthoc test was used for comparison between the rearing environment (MS15 or MS360) and fluid intake (water or

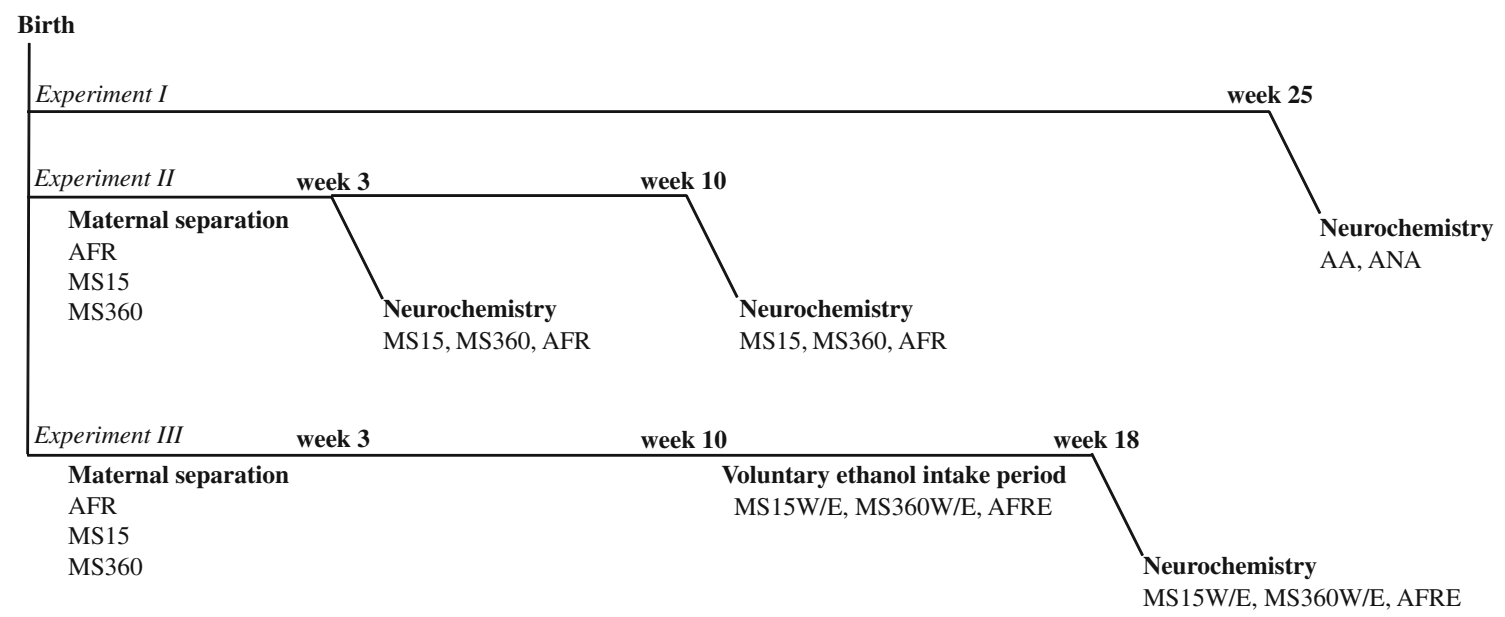

Fig. 1 A schematic overview of the experimental design of the three studies. $A F R$ animal facility rearing, $A A$ alko, alcohol, $A N A$ alko, nonalcohol, $E$ rats having access to ethanol and water, MS15 15 min of maternal separation, MS360 360 min of maternal separation, $W$ rats having access to only water 
ethanol). Statistical analyses were conducted with StatView v5.0.1 (SAS Institute Inc., Cary, NC) for Macintosh computers. Differences were considered significant at $p<0.05$.

\section{Results}

Significant differences in immunoreactive (ir) TFAP- $2 \beta$ protein levels $(F 1,21=5.136 ; p<0.05)$ were detected between adult AA and ANA rats. No MS-induced effects on ir TFAP- $2 \beta$ protein levels were detected in either the juvenile $(F 4,44=1.379 ; p=0.257)$ or adult $(F 4,45=$ $1.482 ; p=0.223)$ rats. No differences ir AP- $2 \beta$ protein levels $(F 4,48=0.630 ; p=0.64)$ were seen between the MS15W, MS15E, MS360W, MS360E and AFRE rats. Comparing the water- and ethanol-drinking MS groups, no significant effects of rearing environment $(F 1,38=0.498$; $p=0.48)$, fluid intake $(F 1,38=0.036 ; p=0.85)$ or interaction between rearing environment and fluid intake $(F 1,38=0.021 ; p=0.89)$ with regard to ir TFAP- $2 \beta$ protein levels were observed (Table 1). The voluntary ethanol consumption has been described in detail elsewhere (Gustafsson and Nylander 2006).

\section{Discussion}

Previous clinical studies have suggested an association between a gene variation in TFAP- $2 \beta$ and personality
(Damberg et al. 2000), severe female alcoholism (Nordquist et al. 2009) and depression in adolescents (Nilsson et al. 2009). It has further been proposed that TFAP- $2 \beta$ may be a target for factors known to influence psychopathological behavior via its effect on transcription of several monoaminergic genes in the central nervous system (for review see Damberg 2005). Further support for this notion stems from findings of effects of antidepressive drugs on brainstem TFAP- $2 \beta$ protein levels in male rats (Berggard et al. 2005 ), indicating a change in the serotonin network in this brain region. In addition, the levels of TFAP- $2 \beta$ protein in the brainstem area are inversely correlated to monoamine turnover in the male rat forebrain (Damberg et al. 2001). Having these factors in mind, we selected the brainstem region, where the serotonin cell bodies are located. Differences in serotonin, dopamine, noradrenaline and opioid systems between the AA and ANA rats have been reported (for review see Sommer et al. 2006). Several genes of importance for these neurocircuitries have consensus sites for TFAP- $2 \beta$. Interestingly, higher levels of ir TFAP- $2 \beta$ levels were seen in the predisposed ethanol-preferring AA rats compared to the non-preferring ANA rats.

MS affects various brain networks, including the dopamine, serotonin and opioid systems (Arborelius and Eklund 2007; Gustafsson et al. 2008; Oreland et al. 2009; Ploj and Nylander 2003; Ploj et al. 2002, 2003b). In the present study, it was hypothesized that the early life environment could affect the levels of TFAP- $2 \beta$ and thereby cause alterations in gene expression of various transmitters,

Table 1 The immunoreactive levels of TFAP- $2 \beta$ protein in the brain stem of male rats

\begin{tabular}{|c|c|c|c|c|c|}
\hline $\begin{array}{l}\text { Rearing } \\
\text { environment }\end{array}$ & Age & $n$ & $\begin{array}{l}\text { Effect of } \\
\text { heredity }\end{array}$ & $\begin{array}{l}\text { Effect of rearing } \\
\text { environment }\end{array}$ & $\begin{array}{l}\text { Effect of rearing environment } \times \\
\text { long-term voluntary ethanol intake }\end{array}$ \\
\hline AA & Adult & 9 & $8.76 \pm 0.37$ & & \\
\hline ANA & Adult & 11 & $6.81 \pm 0.34^{* *}$ & & \\
\hline MS15 & Juvenile & 10 & & $27.45 \pm 1.20$ & \\
\hline MS360 & Juvenile & 10 & & $27.86 \pm 0.73$ & \\
\hline AFR & Juvenile & 9 & & $25.36 \pm 0.47$ & \\
\hline MS15 & Adult & 10 & & $28.64 \pm 1.18$ & \\
\hline MS360 & Adult & 10 & & $33.52 \pm 1.71$ & \\
\hline AFR & Adult & 10 & & $31.70 \pm 1.37$ & \\
\hline MS15 W & Adult & 10 & & & $14.57 \pm 0.95$ \\
\hline MS360 W & Adult & 10 & & & $15.37 \pm 1.10$ \\
\hline MS15E & Adult & 10 & & & $14.89 \pm 0.91$ \\
\hline MS360E & Adult & 12 & & & $15.42 \pm 0.80$ \\
\hline AFRE & Adult & 11 & & & $13.62 \pm 0.95$ \\
\hline
\end{tabular}

Results are shown in mean ng ir TFAP- $\beta$ protein per mg total protein \pm SEM

$A F R$ animal facility rearing, $A A$ alko, alcohol, $A N A$ alko, non-alcohol, $E$ rats having access to ethanol and water, MS15 15 min of maternal separation, MS360 360 min of maternal separation, $n$ number of rats, $W$ rats having access to only water

** $p<0.01$ compared to AA rats (ANOVA followed by Fisher's post-hoc test) 
receptors and transporters. In one previous study, it was reported that short MS is associated with altered hippocampal TFAP-2 gene expression in rats (Meaney et al. 2000). However, our findings suggest no MS-induced differences in brainstem ir TFAP- $2 \beta$ levels in either juvenile or adult male rats. We also measured the ir TFAP- $2 \beta$ brainstem levels in juvenile and adult female rats subjected to litter-wise and individual MS15 and MS360 as well as AFR. Also in this case no differences in ir levels were observed (data not shown). The discrepancy between our and the Meaney study may be due to several factors. First, the AP-2 gene in the Meaney study was measured in another brain area than in our study, thus, making it difficult to compare the results. Second, the subtype of AP-2 gene in the Meaney study was not specified. The TFAP-2 family consists of five known isoforms (for review see Damberg 2005) and one of the isoforms other than TFAP- $2 \beta$ could have been engaged in the differences observed by Meaney and co-workers. Third, alterations in gene expression do not necessarily have to mirror alterations in protein levels. Posttranslational processes may also be affected by the treatment, rat lines, etc.

The early rearing environment has been suggested to be either a protective (short MS) or a risk (prolonged MS) factor for high voluntary ethanol consumption (Roman and Nylander 2005). In addition, Wistar rats subjected to MS were induced to changes in dopamine receptors and opioid peptide levels after long-term, voluntary ethanol self-administration (Ploj et al. 2003a). In another study but using the same animals as Experiment III, differences in ethanol consumption and opioid peptide levels between the experimental groups have previously been reported (Gustafsson and Nylander 2006; Gustafsson et al. 2007). Therefore, we further examined whether different early life experiences would alter ir TFAP- $2 \beta$ levels after longterm voluntary ethanol drinking. However, no differences in ir TFAP- $2 \beta$ levels were observed. Furthermore, no ethanol-induced effects on ir TFAP- $2 \beta$ levels were observed indicating that TFAP- $2 \beta$ is not affected by voluntary ethanol consumption in any of the experimental groups. It is worth mentioning that the standard curve for the immunoassays between the three experiments did not differ from each other. Hence, the method seems to be stable from this point of view. The variations seen between the three experiments are speculated to be due to differences in rat lines (Wistar versus AA/ANA lines) or emotional stress level (due to different housing conditions). The rats in Experiment II, i.e. rats solely exposed to different early rearing conditions, were housed in groups until they were sacrificed. However, the rats in Experiment III, i.e. having access to either water and ethanol or only water, were housed individually for 8 weeks during the entire ethanol access period.
Therefore, we speculate that the differences between the rats in these two experiments might be due to the emotional stress applied in the isolated rats in Experiment III.

In conclusion, our data show that the genetically predisposed ethanol-preferring AA rats and ethanol-avoiding ANA rats differ in ir TFAP- $2 \beta$ protein levels. No differences in ir TFAP- $2 \beta$ protein levels induced by the different early rearing environments were seen in the brainstem of juvenile and adult rats. Furthermore, long-term voluntary ethanol consumption did not alter brainstem TFAP- $\beta$ protein levels in male Wistar rats subjected to MS.

Acknowledgments Grants from the Swedish Research Council K2008-62X-12588-11-3 (I.N.) and 2009-3640 (L.O.) and the Swedish Brain Foundation (L.O.) supported this study.

\section{Conflict of interest None.}

Open Access This article is distributed under the terms of the Creative Commons Attribution Noncommercial License which permits any noncommercial use, distribution, and reproduction in any medium, provided the original author(s) and source are credited.

\section{References}

Arborelius L, Eklund MB (2007) Both long and brief maternal separation produces persistent changes in tissue levels of brain monoamines in middle-aged female rats. Neuroscience 145:738-750

Barr CS, Newman TK, Becker ML, Champoux M, Lesch KP, Suomi SJ, Goldman D, Higley JD (2003) Serotonin transporter gene variation is associated with alcohol sensitivity in rhesus macaques exposed to early-life stress. Alcohol Clin Exp Res $27: 812-817$

Berggard C, Damberg M, Oreland L (2003) Chronic citalopram treatment induces time-dependent changes in the expression and DNA-binding activity of transcription factor AP-2 in rat brain. Eur Neuropsychopharmacol 13:11-17

Berggard C, Damberg M, Oreland L (2005) Brainstem levels of transcription factor AP-2 in rat are changed after treatment with phenelzine, but not with citalopram. BMC Pharmacol 5:1

Caspi A, McClay J, Moffitt TE, Mill J, Martin J, Craig IW, Taylor A, Poulton R (2002) Role of genotype in the cycle of violence in maltreated children. Science 297:851-854

Comb M, Mermod N, Hyman SE, Pearlberg J, Ross ME, Goodman HM (1988) Proteins bound at adjacent DNA elements act synergistically to regulate human proenkephalin cAMP inducible transcription. EMBO J 7:3793-3805

Damberg M (2005) Transcription factor AP-2 and monoaminergic functions in the central nervous system. J Neural Transm 112:1281-1296

Damberg M, Garpenstrand H, Alfredsson J, Ekblom J, Forslund K, Rylander G, Oreland L (2000) A polymorphic region in the human transcription factor AP-2beta gene is associated with specific personality traits. Mol Psychiatry 5:220-224

Damberg M, Eller M, Tonissaar M, Oreland L, Harro J (2001) Levels of transcription factors AP-2alpha and AP-2beta in the brainstem are correlated to monoamine turnover in the rat forebrain. Neurosci Lett 313:102-104

Gustafsson L, Nylander I (2006) Time-dependent alterations in ethanol intake in male wistar rats exposed to short and prolonged 
daily maternal separation in a 4-bottle free-choice paradigm. Alcohol Clin Exp Res 30:2008-2016

Gustafsson L, Zhou Q, Nylander I (2007) Ethanol-induced effects on opioid peptides in adult male Wistar rats are dependent on early environmental factors. Neuroscience 146:1137-1149

Gustafsson L, Oreland S, Hoffmann P, Nylander I (2008) The impact of postnatal environment on opioid peptides in young and adult male Wistar rats. Neuropeptides 42:177-191

Koob GF, Volkow ND (2010) Neurocircuitry of addiction. Neuropsychopharmacology 35:217-238

Ladd CO, Huot RL, Thrivikraman KV, Nemeroff CB, Meaney MJ, Plotsky PM (2000) Long-term behavioral and neuroendocrine adaptations to adverse early experience. Prog Brain Res $122: 81-103$

Lowry OH, Rosebrough NJ, Farr AL, Randall RJ (1951) Protein measurement with the Folin phenol reagent. J Biol Chem 193:265-275

Meaney MJ, Diorio J, Francis D, Weaver S, Yau J, Chapman K, Seckl JR (2000) Postnatal handling increases the expression of cAMPinducible transcription factors in the rat hippocampus: the effects of thyroid hormones and serotonin. J Neurosci 20:3926-3935

Nilsson KW, Sjoberg RL, Wargelius HL, Leppert J, Lindstrom L, Oreland L (2007) The monoamine oxidase A (MAO-A) gene, family function and maltreatment as predictors of destructive behaviour during male adolescent alcohol consumption. Addiction 102:389-398

Nilsson KW, Sjoberg RL, Leppert J, Oreland L, Damberg M (2009) Transcription factor AP-2 beta genotype and psychosocial adversity in relation to adolescent depressive symptomatology. J Neural Transm 116:363-370
Nordquist N, Gokturk C, Comasco E, Nilsson KW, Oreland L, Hallman J (2009) Transcription factor AP2 beta involved in severe female alcoholism. Brain Res 1305(Suppl):S20-S26

Oreland S, Pickering C, Gokturk C, Oreland L, Arborelius L, Nylander I (2009) Two repeated maternal separation procedures differentially affect brain 5-hydroxytryptamine transporter and receptors in young and adult male and female rats. Brain Res 1305(Suppl):S37-S49

Ploj K, Nylander I (2003) Long-term effects on brain opioid and opioid receptor like-1 receptors after short periods of maternal separation in rats. Neurosci Lett 345:195-197

Ploj K, Roman E, Nylander I (2002) Effects of maternal separation on brain nociceptin/orphanin FQ peptide levels in male Wistar rats. Pharmacol Biochem Behav 73:123-129

Ploj K, Roman E, Nylander I (2003a) Long-term effects of maternal separation on ethanol intake and brain opioid and dopamine receptors in male Wistar rats. Neuroscience 121:787-799

Ploj K, Roman E, Nylander I (2003b) Long-term effects of short and long periods of maternal separation on brain opioid peptide levels in male Wistar rats. Neuropeptides 37:149-156

Pryce CR, Feldon J (2003) Long-term neurobehavioural impact of the postnatal environment in rats: manipulations, effects and mediating mechanisms. Neurosci Biobehav Rev 27:57-71

Roman E, Nylander I (2005) The impact of emotional stress early in life on adult voluntary ethanol intake-results of maternal separation in rats. Stress 8:157-174

Sommer W, Hyytia P, Kiianmaa K (2006) The alcohol-preferring AA and alcohol-avoiding ANA rats: neurobiology of the regulation of alcohol drinking. Addict Biol 11:289-309 